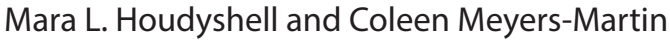 Just give us 10 minutes! A curriculum center takes its message on the road
}

I

wish someone had told me about this place sooner! I didn't even know this was here." Semester after semester, this lament is overheard by the staff at the Teacher Curriculum Center (TCC), located in the Oviatt Library at California State University-Northridge (CSUN). It is usually, and unfortunately, expressed by graduating students, whose college career would have benefited greatly from knowing about TCC and its resources.

Historically, the existence of TCC, hidden on the library's lower level, has been unknown to those needing it the most, those planning careers working with children. This lack of awareness has long been cause for great concern by TCC employees who believed there was a need to increase TCC's profile, both within the library, and more importantly, with the greater campus community.

The need to act upon this concern became a call to action when TCC staff members collectively expressed to each other what they had pondered individually: "If we're here, why aren't the students here?" Staff knew that although some faculty members teaching preK-12 related courses bring their classes to TCC, many do not. TCC staff set out to remedy the situation. If classes weren't coming to TCC, then TCC would go to them. This is how the TCC Roadshow began.

\section{Getting the word out}

To initiate this outreach program, the TCC librarian drafted a letter to inform faculty of the newly established Roadshow. Sent by email to appropriate campus departments and their faculty, the letter describes how TCC employees "roll in and out" of an instructor's classroom, with a TCC resourcefilled cart, in only ten minutes. Guaranteed.

TCC staff members arrive at a classroom with a brightly colored library book truck, carrying a variety of TCC materials. These are items available for student check-out, useful in their course assignments, or for use in their teaching classrooms. The presentation is short, flashy, and fun. The goals for the Roadshow are to be brief, to pique an interest in, and create an awareness of TCC. Professors appreciate the brevity of the Roadshow, its convenience, and the practical information provided.

The majority of Roadshows are presented to classes within the College of Education and the Department of Child \& Adolescent Development. These students are often enrolled in graduate or credential programs. In these presentations, students learn how TCC provides curriculum materials for use in the preK-12 classroom. Materials are available for check-out by CSUN students, staff, faculty, and community members.

Mara L. Houdyshell is reference librarian and director, Teacher Curriculum Center, email: mara.houdyshell@ csun.edu, and Coleen Meyers-Martin is coordinator of outreach services, reference and instruction librarian at California State University-Northridge's Oviatt Library, email: coleen.martin@csun.edu

c 2015 Mara L. Houdyshell and Coleen Meyers-Martin 
What began as a small teacher materials library in the College of Education in the 1960s, grew into TCC. Now housed within the main library, the department serves as a resource for materials that are often unavailable from the Los Angeles Unified School District and private schools in the area. Users are able to borrow materials for two or four-week periods. This allows student teachers, in particular, to avoid out of pocket expenses when creating their lesson plans. Additionally, established classroom teachers and other community members may borrow materials from TCC for a small annual fee.

Details about TCC's instructional materials, as well as the juvenile literature collections, are incorporated within the Roadshows. Staff share information about the size and variety of the collection, more than 18,000 cataloged items. Classroom teaching materials include textbooks, curriculum guides, reference materials, media, instructional games, posters, kits, models, picture sets, puppets; and web resources. The children's and young adult literature collection often serve to support both lesson plans and leisure reading.

Five Roadshows were delivered within the first semester of its programming, fall 2012. As word continued to spread about the Roadshows, the demand has increased. TCC now receives repeat Roadshow requests. Currently, the department receives more than 20 requests, on average, per semester. Staff is happy to visit any CSUN classroom.

The Roadshows are interesting and fun due to staff members who genuinely love speaking about TCC, and also due to the variety of TCC materials that are shared during the presentations.

For example, students learn that TCC carries puppets, such as a polliwog that transforms into a frog, a monarch butterfly, and oversized books such as Clifford the Big Red Dog. Other items of interest demonstrated during the presentation include a Chinese gong and Chilean rain stick.
Such materials are useful visual aids when teaching multicultural curriculums. The Roadshow gives TCC the opportunity to showcase its varied collection, and serves to enliven any teaching unit. There are fruit and vegetable bean bags, a microscope, puzzles, picture sets, and educational board games. Some TCC books can be complimented with corresponding puppets, such as the mouse from If You Give a Mouse a Cookie, or a rainbow fish to accompany the book by the same name. Without a Roadshow demonstration, many students would not anticipate or appreciate all of the varied items and materials TCC offers, and the creative ways in which they can be used.

In instances where a presentation is course-specific, a Roadshow can be tailored for a specialized need or theme. For example, a professor may request resources that are associated with a science project that requires the use of kits or games in order to demonstrate a scientific principle. For most Roadshows, TCC staff also brings materials of general interest, such as The Hunger Games book set with accompanying $\mathrm{CD}$ and die cut templates (alphabetic, numeric, and decorative) used to create bookmarks or to aid in the creation of bulletin boards.

Other information shared in the Roadshow presentation promotes TCC as both a resource and a study space. It is not an official quiet floor in the library, and group work is encouraged. Students are advised, however, to arrive early during busier times of the semester, such as midterms and finals, because seating quickly fills.

In order to create a more inviting environment, TCC was enhanced as campus funds were obtained to upgrade the department. This recent renovation has served to increase the area's popularity. All tables and chairs are now on castors, which enable students to create their own study spaces. Whiteboards are available for use.

The newly renovated space and TCC materials combine to support, not only students in the CSUN College of Educa- 
tion, but also those within the areas of Kinesiology, Children's Literature, and Liberal Studies.

Additional TCC services and department information are discussed during the Roadshows, as well. For example, students can purchase butcher paper for the creation of bulletin boards at just 30 cents a yard. Once students graduate, they can apply for a community user card. Currently $\$ 25$ a year, this membership enables users to have borrowing privileges within TCC. Students appreciate knowing about this service, as it allows them to continue to have access to TCC materials after they graduate.

Feedback about the Roadshows has been extremely positive, as is evidenced by in-person communications, as well as via email. One professor expressed his appreciation, writing, "Thanks for coming to my class yesterday morning. I think it is amazing all the great resources the TCC has to offer and I know I forget. Great idea to take the TCC on the road!"

\section{Creating a campaign}

When we developed our Roadshow and communication campaign, we designed it to be specifically for our curriculum center. We accomplished this through careful planning and implementation. You may consider the following steps when developing a Roadshow and an accompanying outreach program.

1) Define your message. Identify the most vital information about your resources and services your department would like to promote.

2) Define your audience. What groups of people would you most like to target in sharing your message? Considering specific classes, instructors, and campus departments may be a good place to start.

3) Identify communication formats and vehicles. What methods will you choose to deliver your message? A well-rounded approach will include the consideration of classroom visits; tours of your department or center; email messages; library website notifications; and participation within social media outlets as well as word-of-mouth marketing. Often having the support of classroom faculty will help forward your message.

4) Coordinate staffing needs. Is there buy-in? Are there enough staff members within your department to carry out your message within the delivery systems you have selected?

\section{5) Develop marketing materials.} In addition to in-person communication efforts, consider developing print and online resources that will communicate your message such as a website, brochures, bookmarks, and fliers. Online messaging can take place through social media outlets, including Facebook, Twitter, and Instagram.

6) Create an opportunity for your audience. Be certain to include a "call to action" for your audience within your message. This may be an invitation for a class to request a tour of your center or for a staff member to visit a classroom.

7) Evaluate your programming. Encourage input from your audience. Find out if there are additional services that you can provide that would benefit your users. This can be done through a survey, email, in-person communications, or perhaps a combination of these methods.

\section{Conclusion}

During its initial year of programming, the Oviatt Library TCC staff provided more than 25 Roadshows to CSUN students. Currently, TCC staff continues to expand presentations by working with professors they have presented for in the past, and by continuing to reach out to new faculty members. TCC staff has found that professors and students, who invest ten minutes of their time for a Roadshow, gain invaluable information they can use within their current curriculums and future careers. In this way, the TCC Roadshow outreach campaign provides staff with a new vehicle to communicate its purpose and to share the wide variety of resources and services available to CSUN. $\boldsymbol{n}$ 